\title{
The Effects of Adenine Nucleotides on Carbohydrate Metabolism in Pigeon-Liver Homogenates
}

\author{
By W. GEVERS AND H. A. KREBS \\ Medical Research Council Unit for Research in Cell Metabolism, \\ Department of Biochemistry, University of Oxford
}

(Received 2 August 1965)

\begin{abstract}
1. The effects of added AMP on carbohydrate metabolism were investigated in pigeon-liver homogenates, which can degrade glucose and synthesize it from lactate. Suitable experimental conditions were established for studying such effects, including the addition of $\mathrm{P}_{1}(20 \mathrm{~mm})$ to stabilize adenine nucleotides and supplementation with $\mathrm{NAD}^{+}(0.5 \mathrm{~mm})$. 2. Lactate increased the rate of oxygen consumption and kept the concentration of ATP high and that of AMP relatively low. 3. Added AMP $(1 \cdot 25-5 \mathrm{~mm})$ raised the net rate of carbohydrate removal and inhibited the net formation of glucose from lactate, as well as the incorporation of lactate into glucose. These effects were accompanied by a fall in the concentrations of hexose 6-phosphates and a rise in those of fructose diphosphate and triose phosphates. When the activity of glyceraldehyde 3-phosphate dehydrogenase was limited experimentally by a low concentration of $\mathrm{NAD}^{+}$or when it was blocked by iodoacetate, the accumulations of fructose diphosphate and triose phosphates were large and accounted for most of the carbohydrate degraded in the presence of AMP. 4. AMP also inhibited the conversion of pyruvate into phosphoenolpyruvate. Data on the concentrations of pyruvate, phosphoenolpyruvate and intermediates of the tricarboxylic acid cycle, as well as on isotope distribution, suggest that the effect was due to inhibition of phosphoenolpyruvate carboxykinase. 5. The results indicate that in the homogenates phosphofructokinase and fructose diphosphatase, controlled in their activity by adenine nucleotides and other cell constituents, are enzymes which regulate the direction of carbohydrate metabolism (degradation or synthesis) in the liver. 6. It is suggested that active transport of adenine nucleotides, citrate, $\mathrm{Mg}^{2+}, \mathrm{Ca}^{2+}, \mathrm{P}_{\mathrm{i}}$ and other cell constituents may play a role in regulating the activity of enzymes which are affected by these substances. 7. A procedure is described for generating alkali in a closed manometer vessel, by mixing mercuric oxide and a solution of sodium iodide, for use in a method for measuring the oxygen consumption at physiological bicarbonate concentrations.
\end{abstract}

Apart from being reactants in kinase reactions (hexokinase, glucokinase, phosphofructokinase, phosphoglycerokinase, pyruvate kinase) and in oxidative phosphorylation, adenine $5^{\prime}$-nucleotides are known to affect the activity of at least two key enzymes of hepatic carbohydrate metabolism. Phosphofructokinase is inhibited by ATP and deinhibited by ADP and AMP. Fructose diphosphatase is inhibited by AMP. As these activations and inhibitions are taken to be of importance in the regulation of carbohydrate metabolism (see Krebs, $1964 b$ ) the effects of AMP on pigeon-liver homogenates, which can degrade carbohydrate by glycolysis and oxidation, and resynthesize it from lactate and other precursors, were investigated.
Such homogenates form a convenient system for examining further whether the activations and inhibitions found with isolated enzymes may operate in the multi-enzyme system of the liver cells.

\section{METHODS AND MATERIALS}

Materials. The materials were generally as described by Krebs, Dierks \& Gascoyne (1964). Special mention must be made of AMP, ADP, ATP, NAD+ and NADH because of the importance of their purity. AMP was obtained from Waldhof Zellstofffabrik, Mannheim, Germany; ADP was from Sigma Chemical Co., St Louis, Mo., U.S.A.; ATP and $\mathrm{NADH}$, as well as the enzymes required for analyses, were from C. F. Boehringer und Soehne G.m.b.H., Mannheim, Germany. Chromatography of AMP and ADP by the 
method of Eggleston \& Hems (1952) indicated no significant impurities.

Tissue preparations. Homogenates of pigeon liver were prepared as described by Krebs et al. (1964), except that the concentrations of $\mathrm{P}_{\mathrm{i}}$ and $\mathrm{NAD}^{+}$were increased where indicated. To minimize changes in the concentrations of rapidly reacting metabolites during the manipulations after the completion of the incubations, these were terminated by rapid removal of the cups from the water bath, brief immersion, with swirling, in an ethanol-solid $\mathrm{CO}_{2}$ mixture, transfer to a tray of crushed ice and addition of $\mathrm{HClO}_{4}$ to give a final concentration of $2 \%(\mathrm{w} / \mathrm{v})$. After $15 \mathrm{~min}$. at $0^{\circ}$ (sufficient for the extraction of the soluble glycogen) the material was centrifuged at low temperature. A measured sample of the supernatant was neutralized with $\mathrm{KOH}$ in the presence of 2 drops of universal indicator (British Drug Houses Ltd., Poole, Dorset) and the precipitate of $\mathrm{KClO}_{4}$ was removed by centrifugation. The supernatant was diluted to a known volume and stored at $-15^{\circ}$. Analyses for the adenine nucleotides were carried out within a few hours. The rapid cooling and acid treatment gave higher ATP and lower AMP values than rapid acidification alone.

Measurement of gas exchanges. Since low concentrations of $\mathrm{HCO}_{3}$ - ions decrease the rate of gluconeogenesis in pigeon-liver homogenates, the $\mathrm{O}_{2}$ uptake was measured according to the principle of Warburg \& Krippahl (1960), which permits the measurement of the $\mathrm{O}_{2}$ uptake in the presence of physiological concentrations of $\mathrm{CO}_{2}$ and bicarbonate. The $\mathrm{CO}_{2}$ pressure is kept approximately constant by the use of ' $\mathrm{CO}_{2}$ buffers' (Pardee, 1949; Krebs, 1951). Manometer vessels similar to those described by Dickens \& Simer (1931) contained $1 \mathrm{ml}$. of the homogenate in the outer ring and $4 \mathrm{ml}$. of the $\mathrm{CO}_{2}$ buffer, $25 \mathrm{mg}$. of crude carbonic anhydrase [prepared by the method of Meldrum \& Roughton (1933) from bovine erythrocytes] and five small glass beads in the centre compartment. The gas mixture was $\mathrm{CO}_{2}+\mathrm{O}_{2}$ (5:95). In preparing the $\mathrm{CO}_{2}$ buffer solution according to the specifications of Warburg \& Krippahl (1960) and Warburg, Geissler \& Lorenz (1962), it has to be borne in mind that commercial $\mathrm{K}_{2} \mathrm{CO}_{3}$ invariably contains bicarbonate and moisture and the $\mathrm{KHCO}_{3}$ invariably contains some carbonate. The stock solutions were therefore analysed by titration by the method of Kolthoff \& Sandell (1952). A 3 M-buffer giving approximately a mixture in equilibrium with $4 \cdot 2 \% \mathrm{CO}_{2}$ was obtained by dissolving $22 \cdot 0 \mathrm{~g}$. of $\mathrm{KHCO}_{3}$ and $11 \cdot 2 \mathrm{~g}$. of $\mathrm{K}_{2} \mathrm{CO}_{3}$ (both salts from analytical reagents) in a volume of $100 \mathrm{ml}$. The concentration of bicarbonate should be about $2 \cdot 28 \mathrm{M}$ and that of carbonate $0.72 \mathrm{M}$. The $\mathrm{CO}_{2}$ pressure above a given buffer mixture was measured by a modification of the principle used by Krebs (1930) for determining the $\mathrm{CO}_{2}$ content of gas mixtures. $\mathrm{HgO}$ (432 mg.) and crude carbonic anhydrase (25 mg.) were placed in the main compartment of conical Warburg flasks of about $25 \mathrm{ml}$. size fitted with two side arms. Then $1 \mathrm{ml}$. of $4 \mathrm{M}-\mathrm{NaI}$ was pipetted into one side arm and $1 \mathrm{ml}$. of the buffer into the other immediately before attaching the flask to the manometer. A control vessel contained $1 \mathrm{ml}$. of $4 \mathrm{M}-\mathrm{NaCl}$ instead of the buffer and $0.2 \mathrm{ml}$. of $2 \mathrm{~N}-\mathrm{NaOH}$ in the centre well. This measured the small gas-pressure changes (less than $5 \mathrm{~mm}$.) due to changes in vapour pressure. A thermobarometer contained water. The three manometers were equilibrated briefly at the required temperature. With the taps closed and the level of the meniscus so adjusted as to permit a large increase in gas pressure, the buffer was emptied into the main compartment. This caused a rapid output of $\mathrm{CO}_{2}$. When equilibrium had been established, the $\mathrm{NaI}$ solution was tipped into the main compartment, $\mathrm{NaOH}$ was generated by the reaction:

$$
2 \mathrm{NaI}+\mathrm{HgO}+\mathrm{H}_{2} \mathrm{O}=\mathrm{HgI}_{2}+2 \mathrm{NaOH}
$$

and the $\mathrm{CO}_{2}$ in the gas space was rapidly and quantitatively absorbed. The negative pressure change, corrected for changes in the controls, was the equilibrim $\mathrm{CO}_{2}$ pressure over the buffer solution. The $\mathrm{CO}_{2}$ buffers are not perfect absorbers of $\mathrm{CO}_{2}$ and a correction factor ('retention') has to be measured (see Warburg, 1925; Krebs, 1951; Warburg et al. 1962).

To obtain information on the $\mathrm{CO}_{2}$ production of the homogenates another set was incubated in the standard conical Warburg vessels with $\mathrm{CO}_{2}+\mathrm{O}_{2}(5: 95)$ in the gas space. These vessels contained $4 \mathrm{ml}$. of homogenate. The gas-pressure changes recorded in these vessels represented the sum of the $\mathrm{O}_{2}$ consumption and the $\mathrm{CO}_{2}$ formation. These samples also served as the material for the analysis of metabolites.

In a few experiments the $\mathrm{O}_{2}$ uptake and $\mathrm{CO}_{2}$ formation were measured by the principle of Warburg \& Yabusoe (1924). A phosphate-buffered saline medium with low bicarbonate concentrations (up to $5 \mathrm{~mm}$ ) was used.

Analytical procedures. The methods for the determination of glucose, 'glycogen' (i.e. glucose set free by enzyme hydrolysis), L-malate, citrate, $\alpha$-oxoglutarate, L-glutamate and L-lactate were the same as those used by Krebs et al. (1964). Fumarate was estimated as malate after the addition of fumarase. Glucose 6-phosphate and ATP were estimated by the method of Lamprecht \& Trautschold (1963), fructose 6-phosphate by the method of Hohorst $(1963 a)$, fructose 1,6-diphosphate and combined triose phosphate by the method of Bücher \& Hohorst (1963), $\alpha$-glycerophosphate by the method of Hohorst (1963b) and L-aspartate by the method of Pfleiderer (1963). For the determination of the sum of glutamate and glutamine samples were hydrolysed for $2 \mathrm{hr}$. in $2 \mathrm{~N}-\mathrm{H}_{2} \mathrm{SO}_{4}$. The analogous hydrolysis of asparagine was carried out in N-HCl.

Pyruvate, ADP and AMP were estimated in a combined procedure based on that described by Adam (1963), but modified to reduce interfering blanks. These were traced to contamination of ATP samples with ADP, and a variable but significant occurrence of AMP in commercial NADH preparations. The former difficulty was overcome by adding ATP (required in the procedure for the adenylatekinase-catalysed conversion of AMP into ADP) after pyruvate and ADP had been determined, and the second by treating solutions of $\mathrm{NADH}$ with a bacterial alkaline phosphatase (Worthington Biochemical Corp., Freehold, N.J., U.S.A.), as suggested by Lowry, Passonneau, Hasselberger \& Schulz (1964). The value for ADP obtained includes UDP and GDP, and that for ATP includes ITP. The determination of AMP is specific. Though the quantities of uridine nucleotides in liver tissue are significant in relation to those of adenine nucleotides, this is not the case in dilute homogenates to which large amounts of adenine nucleotides have been added. $\mathrm{NAD}^{+}$was determined in the neutral extract by the method of Klingenberg (1963).

Isotopic techniques. [U-14 C]Glucose (obtained from The Radiochemical Centre, Amersham, Bucks.) was used at a 
specific activity of $0 \cdot 25 \mu \mathrm{c} / \mu$ mole. At the end of incubation, $100 \mu$ l. samples of the final neutral extracts were spotted on Whatman no. 1 paper and descending chromatograms in two directions were carried out at room temperature by using the 'semi-stench' of Crowley, Moses \& Ullrich (1962) and butan-1-ol-propionic acid-water (47:22:31, by vol.) as solvents. After being dried, the papers were placed on Kodirex X-ray film (Kodak Ltd., London, W.C. 2) for 3 weeks. A further series of $0.4 \mathrm{ml}$. samples were added to 'diazyme' (Takamine; Miles Chemical Co., Clifton, N.J., U.S.A.; $0.2 \%$ in $0.01 \mathrm{M}$-acetate buffer, $\mathrm{pH} 4.4$ ). These were incubated at $50^{\circ}$ for $2 \mathrm{hr}$. and then heated in a boiling-water bath for $5 \mathrm{~min}$. After centrifugation $200 \mu \mathrm{l}$. samples of the supernatants were chromatographed. Spots were identified by co-chromatography with glucose. The radioactivity of the glucose spots was determined directly on the paper with an end-window Geiger-Müller tube and a Panax scaler (Panax Equipment Ltd., Redhill, Surrey). Both sides of the paper were counted to a minimum of 10000 counts, corrected for background activity, and the mean was taken to be the number of counts/min. in the spot; differences between the two sides were found to be less than $1 \%$. The amount of glucose in the spots proved to be identical with that in the original extracts before chromatography.

The radioactivity of ${ }^{14} \mathrm{CO}_{2}$ formed was measured as follows. The manometer was connected with rubber tubing to a suction system and the $\mathrm{CO}_{2}$ of the gas phase and medium, including the bicarbonate, was collected (Sakami, 1955). As described by Pinter, Hamilton \& Miller (1963), $10 \mu \mathrm{l}$. of the alkali was spotted on a small square of glassfibre filter paper (Whatman GF/A; H. Reeve Angel and Co. Ltd., London, E.C. 4) and placed in a glass vial for liquid-scintillation counting. The sample was dried at $110^{\circ}$ for $10 \mathrm{~min}$. and, after cooling, $10 \mathrm{ml}$. of a scintillation solution [ $700 \mathrm{ml}$. of A.R. toluene, $300 \mathrm{ml}$. of ethanol, $3 \mathrm{~g}$. of 2,5-diphenyloxazole and $0 \cdot 1 \mathrm{~g}$. of 1,4-bis-(5-phenyloxazol2-yl)benzene] was added. The samples were counted in a liquid-scintillation counter (Isotope Developments Ltd., Beenham, Reading, Berks.) and the final values corrected for background activity. The radioactivity of the glucose used in this experiment was determined by the same procedure. The radioactivity was not affected by the addition of $2 \mathrm{~N}-\mathrm{NaOH}$ to the sample on the glass-paper.

\section{RESULTS}

\section{General properties of pigeon-liver homogenates}

Stability of nucleotides. Preliminary experiments indicated that added adenine nucleotides rapidly disappear in pigeon-liver homogenates prepared by the method of Krebs et al. (1964). Most of the added nucleotides was lost within $10-20 \mathrm{~min}$. at $40^{\circ}$, the degradation being mainly due to $5^{\prime}$-AMP deaminase and $5^{\prime}$-nucleotidase (Dresel, 1953; see also Haugaard, Inesi \& Blanken, 1960; Tiedemann $\&$ Born, 1963 ; Berry, 1965). Both these enzymes are known to be inhibited by $P_{1}$ (Kizer, Cox, Lovig \& de Estrugo, 1963; Segal \& Brenner, 1960), and, as expected, increasing the $P_{1}$ concentration in the incubation medium from 4.7 to $20 \mathrm{~mm}$ greatly diminished the loss of nucleotide, especially in the presence of lactate (Table 1). The results shown in Table 1 indicate that the protective effect of lactate at $20 \mathrm{~mm}-P_{i}$ is associated with the maintenance of a high concentration of ATP and a low concentration of AMP, the adenine nucleotide most liable to enzymic hydrolysis. Because of its stabilizing effect, $20 \mathrm{~mm}-\mathrm{P}_{\mathrm{i}}$ was used in most subsequent experiments. Lactate increases the rate of respiration (Krebs et al. 1964), and the maintenance of the ATP concentration is thus probably due to the greater effective-

Table 1. Effect of the concentration of $P_{i}$ on the stability of adenine nucleotides in pigeon-liver homogenates

The data refer to $4 \mathrm{ml}$. of pigeon-liver homogenate prepared and incubated as described in the text. The pigeons were starved for $48 \mathrm{hr}$. Glucose $(5 \mathrm{~mm})$ was added in all experiments. AMP was added as a $0 \cdot 1 \mathrm{~m}$ solution of the disodium salt from the side arm after $20 \mathrm{~min}$. and incubation was continued for another 20 min. The reaction was stopped by rapid cooling (see the text) and the addition of $\mathrm{HClO}_{4}$. 'Preformed' adenine nucleotides refers to the sum of AMP, ADP and ATP found at zero time.

\begin{tabular}{|c|c|c|c|c|c|c|c|c|c|c|}
\hline \multirow[b]{2}{*}{$\begin{array}{l}\text { Expt. } \\
\text { no. }\end{array}$} & \multirow{2}{*}{$\begin{array}{l}\text { Concn. of } \\
\mathrm{P}_{\mathbf{1}} \\
(\mathrm{mM})\end{array}$} & \multirow{2}{*}{$\begin{array}{l}\text { Concn. of } \\
\text { added } \\
\text { lactate } \\
(\mathrm{mM})\end{array}$} & \multirow{2}{*}{$\begin{array}{l}\text { Added } \\
\text { AMP } \\
(\mu \text { moles } / \\
\text { cup) }\end{array}$} & \multirow{2}{*}{$\begin{array}{l}\text { Preformed } \\
\text { adenine } \\
\text { nucleo- } \\
\text { tides } \\
\text { ( } \mu \text { mole/ } \\
\text { cup) }\end{array}$} & \multicolumn{4}{|c|}{$\begin{array}{l}\text { Adenine nucleotides found } \\
\text { at end of incubation } \\
\text { ( } \mu \text { moles/cup) }\end{array}$} & \multirow{2}{*}{$\begin{array}{l}\text { Change of } \\
\text { nucleo- } \\
\text { tides } \\
\text { ( } \mu \text { moles/ } \\
\text { cup) }\end{array}$} & \multirow{2}{*}{$\frac{[\mathrm{AMP}][\mathrm{ATP}]}{[\mathrm{ADP}]^{2}}$} \\
\hline & & & & & ATP & ADP & AMP & Total & & \\
\hline \multirow[t]{2}{*}{1} & 1 & 0 & 10 & 0.86 & $0 \cdot 11$ & 0.55 & $1 \cdot 26$ & 1.91 & -8.94 & 0.46 \\
\hline & 1 & 40 & 10 & $0 \cdot 86$ & 0.43 & 0.88 & 0.82 & $2 \cdot 13$ & $-8 \cdot 73$ & $0 \cdot 46$ \\
\hline \multirow[t]{2}{*}{2} & $4 \cdot 7$ & 0 & 20 & 0.66 & 0.49 & 0.63 & 0.44 & $1 \cdot 56$ & $-19 \cdot 1$ & 0.54 \\
\hline & $4 \cdot 7$ & 40 & 20 & 0.66 & 0.82 & 0.45 & $0 \cdot 13$ & $1 \cdot 40$ & $-19 \cdot 3$ & 0.53 \\
\hline \multirow[t]{4}{*}{3} & 20 & 0 & 10 & $0 \cdot 87$ & 3.98 & $2 \cdot 52$ & $0 \cdot 81$ & $7 \cdot 31$ & $-3 \cdot 56$ & 0.51 \\
\hline & 20 & 40 & 10 & 0.87 & 8.91 & $1 \cdot 68$ & $0 \cdot 20$ & $10 \cdot 8$ & -0.07 & $0 \cdot 63$ \\
\hline & 20 & 0 & 20 & 0.87 & $2 \cdot 32$ & $3 \cdot 58$ & $3 \cdot 50$ & $9 \cdot 40$ & $-11 \cdot 5$ & 0.63 \\
\hline & 20 & 40 & 20 & $0 \cdot 87$ & $12 \cdot 9$ & $2 \cdot 38$ & $0 \cdot 27$ & $15 \cdot 6$ & $-5 \cdot 2$ & $0 \cdot 61$ \\
\hline
\end{tabular}


ness of coupled oxidative phosphorylation in the presence of lactate.

$\mathrm{NAD}^{+}$rapidly disappears during the preparation of the homogenate (see Krebs \& Hems, 1964) and on incubation both endogenous and added $\mathrm{NAD}^{+}$ were extensively degraded under standard conditions. Nicotinamide at $20 \mathrm{~mm}$ inhibited this process. When $\mathrm{NAD}^{+}(0.5 \mathrm{~mm})$ was added to the medium, almost half was lost in $45 \mathrm{~min}$. in the absence of nicotinamide, and about $20 \%$ with 20 mM-nicotinamide. The addition of AMP (2.5 mM) did not affect the rate of $\mathrm{NAD}^{+}$loss nor was this affected by increasing the $P_{1}$ concentration from 5 to $20 \mathrm{~mm}$.

Equilibrium in the adenylate-kinase system. The value of the quotient $[\mathrm{AMP}][\mathrm{ATP}] /[\mathrm{ADP}]^{2}$, as calculated from the data obtained in these experiments, varied between 0.45 and 0.65 , apart from instances where low values for AMP introduced a large error. The equilibrium constant varies between 0.4 and 0.9 with the $\mathrm{Mg}^{2+}$ concentration (H. A. Krebs, W. Gevers \& T. Gascoyne, unpublished work ; see also Bowen \& Kerwin, 1956). Thus adenylate kinase maintained the concentrations of the reactants near the equilibrium position. This reflects the high activity of this enzyme in liver (Oliver, 1955) compared with the rate of ATP synthesis and utilization.

Effects of added AMP on homogenates of liver from starved pigeons, in the absence and presence of lactate

Effects of the addition of AMP on the formation and disappearance of carbohydrate. Glucose was added (5mM) to the homogenates because, unlike those from well-fed birds, livers from starved pigeons contained insufficient carbohydrate to saturate the capacity of the homogenate to metabolize glucose. Added glucose disappeared on incubation and this was greatly accelerated by AMP (Table 2, cups 2 and 3). The formation of glycogen did not account for the removal of glucose. The addition of lactate plus glucose gave rise to substantial gluconeogenesis (cup 5), which was completely abolished by AMP (cup 6). In fact, in this experiment more glucose disappeared in the presence than in the absence of lactate.

Similar effects of AMP were observed in over 20 other experiments. Final AMP concentrations of $1.25 \mathrm{~mm}$ were generally more effective than concentrations of $5 \mathrm{mM}$. At mM- $\mathrm{P}_{1}$, the effect of AMP on glucose disappearance was smaller.

Effects of AMP on the concentration of intermediates of carbohydrate metabolism. The addition of AMP caused characteristic changes in the concentrations of intermediary metabolites (Table 3), which depended on the presence of lactate. When no AMP was added the concentrations of glucose 6-phosphate and fructose 6-phosphate increased on incubation, and these increases were approximately doubled by lactate. The addition of AMP (final concentrations $0 \cdot 1-2 \mathrm{~mm}$ ) led to a fall in the concentrations of both hexose phosphates and abolished the increases found on incubation with lactate.

The most striking changes were those in the concentrations of fructose diphosphate and triose phosphates, which increased more than 100 -fold on the addition of AMP in the absence of lactate. There was a relatively small increase without AMP. Lactate abolished these increases and, instead of fructose diphosphate and triose phosphates, large quantities of $\alpha$-glycerophosphate appeared, especially when AMP was added.

Table 2. Effects of added AMP on carbohydrate metabolism in pigeon-liver homogenate (bird starved for $48 \mathrm{hr}$.)

The data refer to $4 \mathrm{ml}$. of liver homogenate. The medium contained $\mathrm{P}_{1}(20 \mathrm{~mm})$ and $\mathrm{NaHCO}_{3}(25 \mathrm{~mm})$; the gas space contained $\mathrm{CO}_{2}+\mathrm{O}_{2}(5: 95)$. Glucose $(5 \mathrm{~mm})$ was added. AMP was added from a side arm after $15 \mathrm{~min}$. and the incubation was continued for another $30 \mathrm{~min}$. The tissue dry wt. was $80 \mathrm{mg} . / \mathrm{cup}$.

\begin{tabular}{|c|c|c|c|c|c|c|c|c|c|}
\hline $\begin{array}{l}\text { Cup no. } \quad \ldots \\
\text { Additions (other than gluco }\end{array}$ & $\cdots$ & $\ldots$ & Initial & 1 & 2 & 3 & 4 & 5 & 6 \\
\hline Lactate (mM) $\ldots$ & $\ldots$ & $\ldots$ & & & & & 40 & 40 & 40 \\
\hline AMP (mм) & $\ldots$ & $\ldots$ & & & & $2 \cdot 5$ & & & $2 \cdot 5$ \\
\hline Time of incubation (min.) & $\ldots$ & $\ldots$ & 0 & 15 & 45 & 45 & 15 & 45 & 45 \\
\hline \multicolumn{10}{|c|}{ Metabolites found ( $\mu$ moles/cup) } \\
\hline Glucose & & & $2 \cdot 5$ & $19 \cdot 5$ & $14 \cdot 2$ & $5 \cdot 9$ & $23 \cdot 9$ & $\mathbf{2 7 \cdot 5}$ & $6 \cdot 6$ \\
\hline Glucose + glycogen & & & $3 \cdot 9$ & $21 \cdot 1$ & $16 \cdot 8$ & $8 \cdot 5$ & $25 \cdot 5$ & $30 \cdot 5$ & $8 \cdot 4$ \\
\hline Glycogen & & & $1 \cdot 4$ & $1 \cdot 6$ & $2 \cdot 6$ & $2 \cdot 6$ & $1 \cdot 6$ & $\mathbf{3} \cdot \mathbf{0}$ & $1 \cdot 8$ \\
\hline \multicolumn{10}{|c|}{$\begin{array}{l}\text { Changes between } 15 \text { and } 45 \mathrm{~min} \text {. } \\
\text { ( } \mu \text { moles/cup) }\end{array}$} \\
\hline Glucose & & & & & $-5 \cdot 3$ & $-13 \cdot 6$ & & $+3 \cdot 6$ & $-17 \cdot 3$ \\
\hline Glucose + glycogen & & & & & $-4 \cdot 3$ & $-12 \cdot 6$ & & $+5 \cdot 0$ & $-17 \cdot 1$ \\
\hline Glycogen & & & & & $+1 \cdot 0$ & $+1 \cdot 0$ & & $+1 \cdot 5$ & $+0 \cdot 3$ \\
\hline
\end{tabular}


Table 3. Effects of AMP on the concentration of intermediates of carbohydrate metabolism in pigeon-liver homogenate (starved bird)

The data refer to the same experiment for which values for glucose and glycogen are given in Table 2 .

\begin{tabular}{|c|c|c|c|c|c|c|c|}
\hline $\begin{array}{lllll}\text { Cup no. } & \ldots & \ldots & \ldots & \ldots \\
\text { Additions other than glucose } & \ldots\end{array}$ & $\begin{array}{ll}\ldots & \text { Initial } \\
\ldots & \end{array}$ & $\begin{array}{c}1 \\
\text { None }\end{array}$ & $\begin{array}{c}2 \\
\text { None }\end{array}$ & $\begin{array}{l}3 \\
\text { AMP }\end{array}$ & $\begin{array}{c}4 \\
\text { Lactate }\end{array}$ & $\begin{array}{c}5 \\
\text { Lactate }\end{array}$ & $\begin{array}{c}6 \\
\text { Lactate } \\
+ \text { AMP }\end{array}$ \\
\hline Time of incubation (min.) & $\ldots$ & 15 & 45 & 45 & 15 & 45 & 45 \\
\hline \multicolumn{8}{|l|}{ Intermediates found ( $\mu$ moles/cup) } \\
\hline Glucose 6-phosphate & $0 \cdot 13$ & 0.74 & $0 \cdot 63$ & $0 \cdot 18$ & $1 \cdot 39$ & $1 \cdot 10$ & 0.59 \\
\hline Fructose 6-phosphate & 0.04 & $0 \cdot 20$ & $0 \cdot 15$ & 0.04 & 0.40 & 0.30 & $0 \cdot 10$ \\
\hline Fructose 1,6-diphosphate & 0.02 & 0.02 & $0 \cdot 12$ & $8 \cdot 46$ & 0.03 & 0.03 & $0 \cdot 13$ \\
\hline Triose phosphates & $0 \cdot 08$ & $0 \cdot 11$ & 0.41 & $9 \cdot 71$ & $0 \cdot 12$ & $0 \cdot 14$ & 0.42 \\
\hline$\alpha$-Glycerophosphate & $0 \cdot 26$ & $0 \cdot 18$ & 0.58 & 0.90 & $8 \cdot 18$ & $4 \cdot 28$ & $15 \cdot 1$ \\
\hline 3-Phosphoglycerate & $0 \cdot 20$ & $0 \cdot 16$ & $0 \cdot 14$ & 0.08 & $1 \cdot 10$ & 1.24 & $0 \cdot 28$ \\
\hline 2-Phosphoglycerate & 0.06 & 0.06 & 0.05 & 0.02 & $0 \cdot 16$ & 0.17 & 0.04 \\
\hline Phosphoenolpyruvate & $0 \cdot 12$ & 0.09 & 0.09 & 0.03 & 0.55 & 0.66 & $0 \cdot 10$ \\
\hline Pyruvate & $0 \cdot 10$ & 0.07 & $0 \cdot 10$ & $0 \cdot 11$ & $0 \cdot 37$ & $0 \cdot 38$ & $0 \cdot 27$ \\
\hline Lactate & $1 \cdot 47$ & 0.23 & $0 \cdot 80$ & 0.81 & 140 & $97 \cdot 5$ & $89 \cdot 0$ \\
\hline Changes in lactate ( $\mu$ moles/cup) & - & $-1 \cdot 24$ & -0.67 & -0.68 & $-21 \cdot 5$ & $-64 \cdot 0$ & $-72 \cdot 5$ \\
\hline
\end{tabular}

The accumulation of fructose diphosphate and triose phosphates did not occur in homogenates from starved birds to which no glucose was added; in other words, the presence of glucose or glycogen was a prerequisite of the accumulation. This suggests that the bulk of the three intermediates was derived from carbohydrate rather than from gluconeogenic precursors. Results similar to those in Table 3 were obtained in every experiment where (1) the AMP concentration measured at the end of incubation was $0.1 \mathrm{mM}$ or higher, (2) the concentration of added $\mathrm{NAD}^{+}$was $0.125 \mathrm{~mm}$ or less, (3) glucose was added and (4) the concentration of $P_{i}$ was $5 \mathrm{~mm}$ or more. Greater amounts of 3-phosphoglycerate, 2-phosphoglycerate, phosphoenolpyruvate and pyruvate were found at the end of the incubation in the presence than in the absence of lactate, but AMP caused a fall in the concentrations of all four intermediates with and without lactate. This fall was greatest for phosphoenolpyruvate and least for pyruvate.

These observations are all in agreement with the assumption that rate-limiting reactions and the factors controlling the rates in the homogenates are the following (only activations and inhibitions relevant to the interpretation of the observations are listed): (1) phosphofructokinase, activated by AMP and ADP (Passonneau \& Lowry, 1964; Underwood \& Newsholme, 1965b); (2) hexokinase, inhibited by glucose 6-phosphate (Weil-Malherbe \& Bone, 1951; Crane \& Sols, 1954); (3) fructose diphosphatase, inhibited by AMP and by fructose diphosphate above 0.1 mM (Taketa \& Pogell, 1963; Underwood \& Newsholme, 1965a); (4) triose phosphate dehydrogenase, limited in the direction of glycolysis by a low concentration of $\mathrm{NAD}^{+}$far below the $K_{m}$ value of the enzyme for $\mathrm{NAD}^{+}$, but almost fully active in the reverse direction (assuming that the $K_{m}$ values are of the same order as for rabbit-muscle triose phosphate dehydrogenase, where $K_{m}$ for NAD at $\mathrm{pH} 7 \cdot 4$ and $26^{\circ}$ is $100 \mu \mathrm{M}$ and that for NADH is $3 \cdot 3 \mu \mathrm{M}$; Velick \& Furfine, 1963).

The three changes that occur on the addition of AMP, namely the rise in the concentrations of fructose diphosphate and triose phosphates, the fall in those of hexose 6-phosphates and the increased removal of glucose, can be accounted for by the behaviour of phosphofructokinase (effect 1), plus the increased activity of hexokinase (effect 2). The inhibition of fructose diphosphatase by AMP and fructose diphosphate (effect 3) accounts for the flow of carbohydrate metabolism in the direction of glycolysis as opposed to gluconeogenesis. That glycolysis does not proceed beyond the formation of triose phosphate and causes an accumulation of fructose diphosphate and triose phosphates is due to effect 4.

The changes that occur in the presence of lactate and absence of added AMP, namely a fall in the concentration of fructose diphosphate and rise in those of hexose 6-phosphates, are accounted for by the de-inhibition of fructose diphosphatase (effect $3)$. The occurrence of a net synthesis of carbohydrate shows that triose phosphate dehydrogenase is active in the reduction of 1,3-diphosphoglycerate (effect 4), as expected on account of the measured concentration of NADH in the homogenate (6$10 \mu \mathrm{M}$; Krebs \& Hems, 1964). The rise in concentrations of the phosphoglycerates and phosphoenolpyruvate in the presence of lactate suggests that the formation of these intermediates is more rapid than their removal. 
Table 4. Effect of $N A D^{+}$concentration on carbohydrate utilization in pigeon-liver homogenate (starved bird)

Each cup contained $4 \mathrm{ml}$. of homogenate (dry wt. $69 \mathrm{mg}$.) prepared as described in the Methods and Materials section and incubated for $45 \mathrm{~min}$. AMP was added at $15 \mathrm{~min}$. The homogenate contained initially ( $\mu \mathrm{moles} / \mathrm{cup}$ ): glucose plus glycogen, $3 \cdot 2$; glucose, $1 \cdot 8$; fructose diphosphate, $0 \cdot 03$; triose phosphates, $0 \cdot 13 ; \alpha$-glycerophosphate, $0 \cdot 37$.

\begin{tabular}{|c|c|c|c|c|c|c|}
\hline \multirow{2}{*}{\multicolumn{7}{|c|}{$\begin{array}{l}\text { Cup no. } \\
\text { Additions: }\end{array}$}} \\
\hline & & & & & & 5 \\
\hline $\mathrm{NAD}^{+}(\mathrm{mM})$ & $\begin{array}{l}\cdots \\
\cdots\end{array}$ & $\begin{array}{l}\cdots \\
\cdots\end{array}$ & 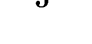 & 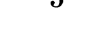 & 0.5 & $0 \cdot 5$ \\
\hline $\operatorname{AMP}(\mathrm{mm})$ & $\ldots$ & $\ldots$ & & $2 \cdot 5$ & & $2 \cdot 5$ \\
\hline \multicolumn{7}{|c|}{$\begin{array}{l}\text { Changes in compounds } \\
(\mu \text { moles/cup })\end{array}$} \\
\hline \multicolumn{3}{|c|}{ Glucose + glycogen } & $-6 \cdot 8$ & $-11 \cdot 4$ & -8.5 & $-13 \cdot 3$ \\
\hline \multicolumn{3}{|l|}{ Glucose } & $-9 \cdot 0$ & $-13 \cdot 2$ & $-0 \cdot 4$ & $-14 \cdot 7$ \\
\hline \multicolumn{3}{|c|}{ Fructose diphosphate } & +0.44 & $+4 \cdot 61$ & +0.04 & $+0 \cdot 13$ \\
\hline \multicolumn{3}{|c|}{ Triose phosphates } & $+1 \cdot 71$ & $+6 \cdot 87$ & $+0 \cdot 05$ & $+0 \cdot 16$ \\
\hline \multicolumn{3}{|c|}{$\alpha$-Glycerophosphate } & $+0 \cdot 07$ & $+0 \cdot 31$ & $-0 \cdot 20$ & -0.09 \\
\hline
\end{tabular}

Effects of $\mathrm{NAD}^{+}$concentration in the absence of lactate. Adding 4 times as much $\mathrm{NAD}^{+}(0.5 \mathrm{~mm})$ to the homogenate as in previous experiments increased the disappearance of carbohydrate on incubation. The addition of AMP $(2.5 \mathrm{mM})$ further accelerated the removal (Table 4). At this higher $\mathrm{NAD}^{+}$concentration the addition of AMP caused no accumulation of fructose diphosphate and triose phosphates. The observations are accounted for by the rate-limiting function of $\mathrm{NAD}^{+}$in the triose phosphate-dehydrogenase system (effect 4). At $0.5 \mathrm{~mm}-\mathrm{NAD}^{+}$this step no longer blocks the degradation of triose phosphate. Hence, in the absence of lactate, more glucose is broken to the stages of pyruvate and beyond, and this breakdown is greatly enhanced by AMP (effects 1, 2 and 3). This interpretation is confirmed by another experiment in which the yield of ${ }^{14} \mathrm{CO}_{2}$ from [U-14 C]glucose $(2.5 \mathrm{~mm})$ was determined during a $30 \mathrm{~min}$. incubation after the addition of AMP $(2.5 \mathrm{~mm})$ in the absence of lactate. AMP caused a 2.5-fold increase in the number of counts in carbon dioxide.

Effect of $\mathrm{NAD}^{+}$concentration in the presence of lactate. The synthesis of carbohydrate in the presence of lactate was not affected by the addition of $\mathrm{NAD}^{+}(0.5 \mathrm{~mm})$ (effect 4$)$. A detailed analysis of the effects of AMP in such homogenates to which lactate and $\left[\mathrm{U}-{ }^{14} \mathrm{C}\right]$ glucose were added, and where gluconeogenesis predominated over glycolysis, was made in a further experiment (Table 5). The synthesis of carbohydrate that occurred in the absence of AMP was associated with a progressive fall in the specific activity both of glucose and of glucose plus glycogen until, at $90 \mathrm{~min}$., it was less than half the starting value. However, only about one-fifth of the total radioactivity was not recovered as glucose or glycogen, which indicates a lower rate of glucose degradation under the test conditions (i.e. in the presence of lactate). In contrast, there was a net disappearance of glucose in the early stages after the addition of AMP, whereas the concentration of AMP, which fell (cup 3) from 2.5 to $0.23 \mathrm{~mm}$ in $15 \mathrm{~min}$., remained high enough to inhibit. When the concentration of AMP dropped further to $0.14 \mathrm{~mm}$ after $60 \mathrm{~min}$., a net synthesis of glucose began. There was no fall in the specific activity of glucose until net synthesis occurred. The data for the radioactivity of glucose plus glycogen were similar to those found for free glucose; hence the fall in specific activity was not due to the formation of glucose from glycogen.

The concentrations of intermediates in these experiments were very similar to those given in Table 3, describing an experiment where the concentration of added $\mathrm{NAD}^{+}$was $0.125 \mathrm{~mm}$, except that the concentration of fructose diphosphate at no stage rose above $0.01 \mathrm{~mm}$ (Table 5). Adding $\mathrm{NAD}^{+}$ $(0.5 \mathrm{~mm})$ did not abolish the extra formation of $\alpha$-glycerophosphate caused by the addition of AMP in the presence of high concentrations of lactate. The amount of radioactivity in $\alpha$-glycerophosphate increased sharply (Table 5). During the first $15 \mathrm{~min}$. after AMP addition, 41900 counts $/ \mathrm{min}$. were lost from glucose, of which 33700 counts/min. appeared in $\alpha$-glycerophosphate; the net increase in the latter was $5 \cdot 12 \mu$ moles/cup, which would, if derived entirely from glucose, account for 31600 counts/min. Thus AMP, on balance, caused a breakdown of carbohydrate to the level of triose phosphate; but, in the presence of lactate, triose phosphate was not dehydrogenated (effect 4) but reduced to $\alpha$-glycerophosphate in accordance with the reaction:

\section{Lactate + dihydroxyacetone phosphate} $=$ pyruvate $+\alpha$-glycerophosphate 


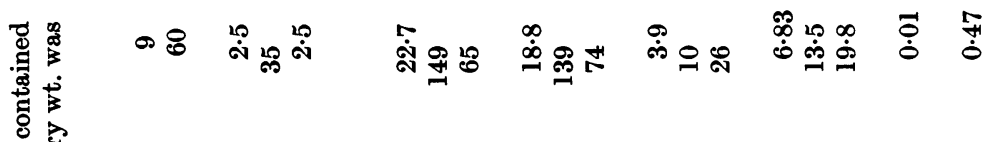

เร

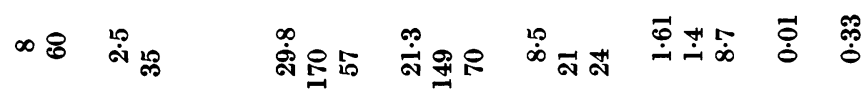

$\sim 8$ ஸे

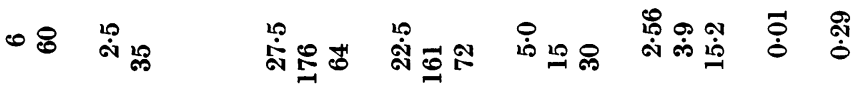

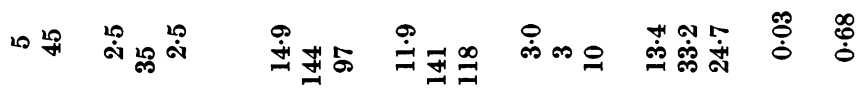

+ 난

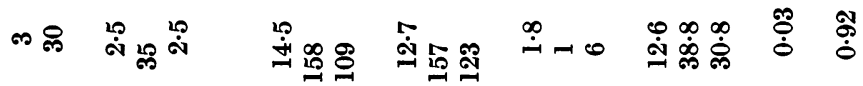

N

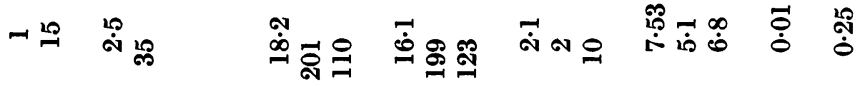

营

$\vdots \quad \vdots \quad \vdots \quad \vdots$

เง घี 을

离

总离

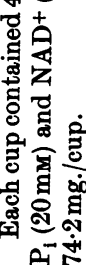

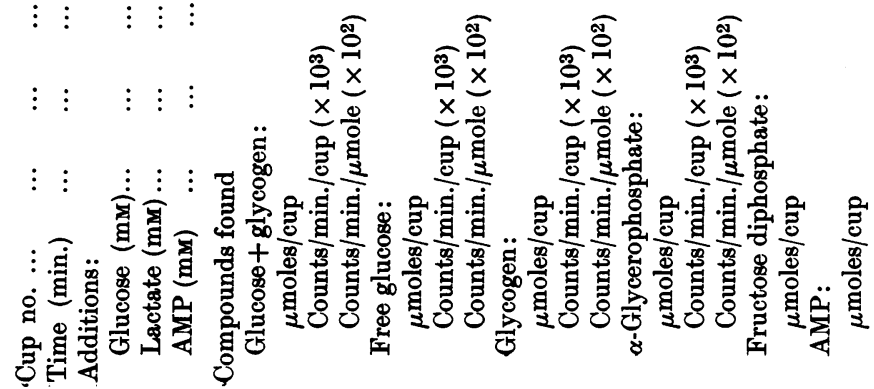


Table 6. Equilibrium between two linked dehydrogenase systems in pigeon-liver homogenate

The values given refer to the experiment described in Table 5. Determinations were carried out as indicated in the Methods and Materials section. The value for dihydroxyacetone phosphate was calculated from that for the sum of triose phosphates, assuming that there was equilibrium in the triose phosphate-isomerase system and that $K=$ [dihydroxyacetone phosphate]/[glyceraldehyde 3-phosphate] =22 (Baronowski, 1949). $E_{0}^{\prime}$ values of the lactate-pyruvate and $\alpha$-glycerophosphate-dihydroxyacetone phosphate couples at $25^{\circ}$ were taken to be -0.185 and $-0.192 \mathrm{v}$ respectively (Burton, 1957), and the expected ratio $K=$ [ $\alpha$-glycerophosphate] [pyruvate]/ [lactate] [dihydroxyacetone phosphate] $=0.58$ was derived from the relation $\Delta E_{0}^{\prime}=0.03 \log K$.

\begin{tabular}{|c|c|c|c|c|c|c|c|}
\hline \multirow[b]{2}{*}{ Cup no. } & \multirow[b]{2}{*}{ Time (min.) } & \multicolumn{5}{|c|}{ Compounds found ( $\mu$ moles/cup) } & \multirow[b]{2}{*}{$K$} \\
\hline & & $\begin{array}{l}\text { Added AMP } \\
(\mu \text { moles/cup })\end{array}$ & Lactate & $\begin{array}{l}\text { Dihydroxy- } \\
\text { acetone } \\
\text { phosphate }\end{array}$ & Pyruvate & $\begin{array}{l}\alpha \text {-Glycero- } \\
\text { phosphate }\end{array}$ & \\
\hline 1 & 15 & 0 & 124 & $0 \cdot 16$ & 1.51 & $7 \cdot 53$ & 0.57 \\
\hline 2 & 30 & 0 & 115 & $0 \cdot 19$ & $1 \cdot 81$ & $6 \cdot 79$ & 0.56 \\
\hline 3 & 30 & 10 & 101 & 0.32 & 1.08 & $12 \cdot 6$ & 0.42 \\
\hline 4 & 45 & 0 & 88.9 & 0.15 & 1.86 & $4 \cdot 08$ & 0.57 \\
\hline 5 & 45 & 10 & $79 \cdot 0$ & 0.34 & 0.93 & $13 \cdot 4$ & 0.47 \\
\hline 6 & 60 & 0 & $75 \cdot 3$ & 0.14 & $1 \cdot 84$ & $2 \cdot 56$ & 0.45 \\
\hline 7 & 60 & 10 & $63 \cdot 1$ & 0.29 & $0 \cdot 85$ & $12 \cdot 9$ & $0 \cdot 60$ \\
\hline 8 & 90 & 0 & $54 \cdot 0$ & 0.15 & 0.72 & $1 \cdot 61$ & $0 \cdot 14$ \\
\hline 9 & 90 & 10 & $35 \cdot 6$ & 0.24 & 0.84 & $6 \cdot 83$ & $0 \cdot 67$ \\
\hline
\end{tabular}

Table 7. Effects of AMP on the formation of intermediates of the tricarboxylic acid cycle and related amino acids in pigeon-liver homogenates in the presence of lactate (starved bird)

Each cup contained $4 \mathrm{ml}$. of homogenate prepared as described in the Methods and Materials section and incubation was for $60 \mathrm{~min}$. The medium contained $P_{1}(20 \mathrm{mM})$ and $\mathrm{NAD}^{+}(0.5 \mathrm{~mm})$. AMP was present in cup 2 from zero time. The calculation of 'lactate equivalents' was made according to the principles described by Berry (1965) for the calculation of 'pyruvate equivalents' of intermediates measured. The tissue dry wt. was $80.4 \mathrm{mg}$./cup.

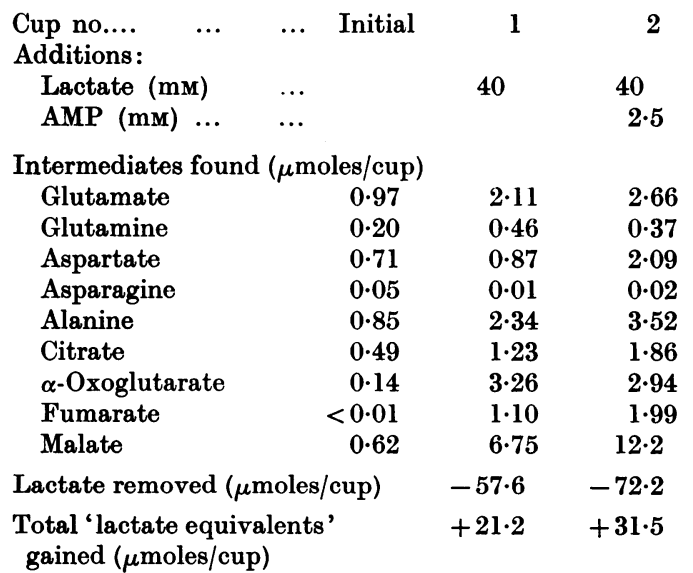

The concentrations of the four reactants were close to those of the equilibrium state (Table 6).

At the same time, AMP inhibited the initial stages of gluconeogenesis from lactate to triose phosphate, as indicated by the fact that lactate carbon was not incorporated into glucose or $\alpha$ glycerophosphate. This inhibition was not due to decreased utilization of lactate because the data in Table 7 show that more lactate was removed when AMP was added. The conclusion must be drawn that AMP above a critical concentration causes pyruvate to undergo oxidation rather than conversion into phosphoenolpyruvate. This effect could be exerted either by stimulation of the rate of pyruvate oxidation or by the inhibition of an enzyme concerned with the synthesis of phosphoenolpyruvate.

Evidence in favour of the first possibility is: $(a)$ the increase in the rate of oxygen uptake, and increased oxidation of lactate to carbon dioxide, caused by AMP (see below), presumably related to the formation of ADP by the action of adenylate kinase; $(b)$ the fall in the steady-state concentration of pyruvate to about half that found in the absence of AMP (Table 6).

Evidence in favour of the second possibility is: (a) the fall in the concentration of phosphoenolpyruvate (and in that of the phosphoglycerates) caused by AMP (Table 2), which could be due to diminished activity of phosphoenolpyruvate carboxykinase or to enhanced action of pyruvate kinase; (b) the rise in the concentration of malate to nearly double that found when AMP was not added, in conjunction with the increased rate of formation of other intermediates of the tricarboxylic acid cycle and related amino acids (Table 7). This suggests that pyruvate carboxylase is not 
affected by AMP or by the products of its metabolism. However, an inhibition of phosphoenolpyruvate carboxykinase, the second enzyme responsible in avian liver for the conversion of pyruvate into phosphoenolpyruvate, could account for the effects of AMP, a point that requires further investigation. It is noteworthy that Holten \& Nordlie (1965) have in fact observed an inhibition of guinea-pig-liver mitochondrial phosphoenolpyruvate carboxykinase by AMP.

Effect of AMP on gas exchanges of pigeon-liver homogenate. The addition of glucose alone caused a small increase in the oxygen consumption, and a further rise, under optimum conditions, of about $50 \%$ was brought about by AMP (Table 8). Optimum conditions included the presence of $20 \mathrm{~mm}-\mathrm{P}_{1}$ and $5 \mathrm{~mm}$-bicarbonate or more in the medium: the effect was slight when the concentration of $P_{1}$ was $1 \mathrm{mM}$, and without bicarbonate there was no stimu- lation by AMP. Lactate alone also caused a great increase in oxygen uptake (about $100 \%$ ) and the extra rise due to AMP was only $20-30 \%$. Varying the concentration of added AMP from 1.25 to $5 \mathrm{mM}$ made little difference. At $2.5 \mathrm{~mm}$ the rise in oxygen uptake was progressive with time (Table 9); at $5 \mathrm{~mm}$ initial stimulation was followed by inhibition when the concentration of $P_{1}$ was $5 \mathrm{~mm}$, and in the latter case extensive losses of adenine nucleotides occurred during the incubation. The inhibition was probably due to an effect of ammonia set free from AMP (see Recknagel \& Potter, 1951; Berry, 1964). The respiratory quotient was $\mathbf{0 . 8 5}$ under standard conditions (Table 8, Expt. 1) and the addition of AMP did not change this value despite the large increases in the consumption of both oxygen and carbohydrate.

In homogenates containing very small initial quantities of carbohydrate and to which no glucose

\section{Table 8. Effects of AMP on gas exchange in pigeon-liver homogenate (starved bird)}

In each experiment, $4 \mathrm{ml}$. of homogenate was incubated for $45 \mathrm{~min}$.; full details of procedure are given in the Methods and Materials section. The $P_{1}$ concentration was $20 \mathrm{~mm}$. Experiments were carried out with and without AMP (5 mM in Expt. 1 and $2.5 \mathrm{~mm}$ in the others), which was added from a side arm at $15 \mathrm{~min}$. $\mathrm{CO}_{2}$ buffers were used in Expt. 1 and the method of Warburg \& Yabusoe (1924) in Expts. 2-5. The gas measurements refer to the periods 15-45 min. The tissue dry wt. varied from 70 to $80 \mathrm{mg}$. Expt. 1 is the same as that described in Tables 2 and 3, where values for changes in carbohydrates and intermediates are given. R.Q., Respiratory quotient.

\begin{tabular}{|c|c|c|c|c|c|c|c|c|c|}
\hline \multirow[b]{2}{*}{$\begin{array}{c}\text { Expt. } \\
\text { no. }\end{array}$} & \multirow[b]{2}{*}{$\begin{array}{l}\text { Substrate } \\
\text { added }\end{array}$} & \multirow[b]{2}{*}{$\begin{array}{c}\text { Concn. of } \\
\text { substrate } \\
\quad(\mathrm{mM})\end{array}$} & \multirow{2}{*}{$\begin{array}{l}\text { Concn. of } \\
\text { added } \\
\mathrm{NAD}^{+} \\
(\mathrm{mm})\end{array}$} & \multirow[b]{2}{*}{$\begin{array}{c}\text { Concn. of } \\
\mathrm{HCO}_{3}^{-} \\
(\mathrm{mM})\end{array}$} & \multicolumn{2}{|c|}{ Without AMP } & \multicolumn{2}{|c|}{ With AMP } & \multirow{2}{*}{$\begin{array}{c}\text { Increase } \\
\text { of } \mathrm{O}_{2} \\
\text { uptake } \\
\text { caused } \\
\text { by AMP } \\
(\%)\end{array}$} \\
\hline & & & & & $\begin{array}{c}\mathrm{O}_{2} \text { uptake } \\
(\mu \text { moles/cup })\end{array}$ & R.Q. & $\begin{array}{c}\mathrm{O}_{2} \text { uptake } \\
(\mu \text { moles/cup })\end{array}$ & R.Q. & \\
\hline $1 C$ & Glucose & 5 & $0 \cdot 125$ & 25 & $-39 \cdot 8$ & $0 \cdot 85$ & $-61 \cdot 3$ & 0.85 & 54 \\
\hline & Glucose, lactate & 5,40 & 0.125 & 25 & $-56 \cdot 4$ & 0.55 & $-72 \cdot 0$ & 0.59 & 27 \\
\hline 20 & Glucose & 5 & $0 \cdot 125$ & 0 & $-32 \cdot 0$ & $0 \cdot 84$ & $-33 \cdot 4$ & 0.85 & 4 \\
\hline 30 & Glucose & 5 & $0 \cdot 125$ & 5 & $-34 \cdot 1$ & 0.91 & $-50 \cdot 8$ & 0.90 & 49 \\
\hline $4 \mathrm{C}$ & Glucose & 5 & 0.5 & 5 & $-33 \cdot 5$ & $0 \cdot 85$ & $-42 \cdot 2$ & 0.95 & 26 \\
\hline 51 & None & & $0 \cdot 125$ & 5 & $-25 \cdot 2$ & 0.89 & $-30 \cdot 9$ & $0 \cdot 88$ & 23 \\
\hline
\end{tabular}

Table 9. Time-course of AMP effect on oxygen uptake by pigeon-liver homogenate

Conditions were as described in Table 8 and Expt. 1 corresponds to Expt. 1 of that Table. $\mathrm{CO}_{2}$ buffers were used to measure the uptake of $\mathrm{O}_{2}$. AMP was added at $15 \mathrm{~min}$. The tissue dry wt. was $80 \mathrm{mg}$. $/ \mathrm{cup}$ in the first experiment and $75 \mathrm{mg} . /$ cup in the second.

\begin{tabular}{|c|c|c|c|c|c|c|c|c|}
\hline \multirow{2}{*}{$\begin{array}{c}\text { Expt. } \\
\text { no. }\end{array}$} & \multirow{2}{*}{$\begin{array}{l}\text { Substrate } \\
\text { added }\end{array}$} & \multirow{2}{*}{$\begin{array}{l}\text { Concn. of } \\
\text { substrate } \\
\text { (mM) }\end{array}$} & \multirow{2}{*}{$\begin{array}{l}\text { Conen. } \\
\text { of } P_{i} \\
(\mathrm{mM})\end{array}$} & \multirow{2}{*}{$\begin{array}{c}\text { Concn. of } \\
\text { added } \\
\text { AMP } \\
(\mathrm{mM})\end{array}$} & \multicolumn{3}{|c|}{$\begin{array}{c}\mathrm{O}_{2} \text { uptake } \\
(\mu \text { moles/cup) }\end{array}$} & \multirow{2}{*}{$\begin{array}{c}\text { of adenine } \\
\text { nucleotides } \\
\text { during } \\
\text { incubation } \\
\text { ( } \mu \text { moles } / \text { cup) }\end{array}$} \\
\hline & & & & & 0-15 min. & $15-30 \mathrm{~min}$. & $30-45 \mathrm{~min}$. & \\
\hline \multirow[t]{4}{*}{1} & Glucose & 5 & 20 & 0 & $-20 \cdot 8$ & $-20 \cdot 2$ & $-19 \cdot 6$ & - \\
\hline & Glucose & 5 & 20 & $2 \cdot 5$ & $-20 \cdot 7$ & $-27 \cdot 8$ & -33.5 & $-3 \cdot 4$ \\
\hline & Glucose, lactate & 5,40 & 20 & 0 & $-32 \cdot 2$ & $-30 \cdot 3$ & $-26 \cdot 1$ & - \\
\hline & Glucose, lactate & 5,40 & 20 & $2 \cdot 5$ & $-32 \cdot 2$ & $-33 \cdot 5$ & $-38 \cdot 5$ & $-0 \cdot 1$ \\
\hline \multirow[t]{2}{*}{2} & Glucose & 5 & 5 & 0 & $-22 \cdot 1$ & $-21 \cdot 5$ & $-21 \cdot 1$ & - \\
\hline & Glucose & 5 & 5 & 5 & $-22 \cdot 0$ & $-27 \cdot 4$ & $-11 \cdot 2$ & $-18 \cdot 4$ \\
\hline
\end{tabular}


was added the increase in oxygen uptake brought about by AMP was only $23 \%$ (Table 8, Expt. 5). Virtually all the preformed glucose and glycogen disappeared on incubation whether AMP was added or not.

\section{Effects of added AMP on liver homogenates from well-fed pigeons}

Effects of AMP on the formation and degradation of carbohydrate. In homogenates of liver from wellfed pigeons, AMP caused an increase in the rate of disappearance of total carbohydrate, mainly glucose (Table 10). When lactate was added, some gluconeogenesis occurred, but as described by
Krebs et al. (1964) the rate was low. When AMP and lactate were added together no net synthesis of carbohydrate occurred but much carbohydrate disappeared. The absolute effect of AMP when corrected for the control without AMP was about the same without lactate (cups 2 and $3: 10 \cdot 3 \mu$ moles) and with lactate (cups 5 and $6: 11 \cdot 1 \mu$ moles).

Effects of AMP on the concentration of intermediates. The effects of AMP on the concentrations of intermediates were similar to those found in homogenates from starved pigeons (Table 11). When $\mathrm{NAD}^{+}$was added at $0.5 \mathrm{~mm}$, fructose diphosphate and triose phosphates did not accumulate. Iodoacetate at $0.25 \mathrm{~mm}$ (in the absence of lactate) and $\mathrm{NAD}^{+}$added at $0.5 \mathrm{~mm}$ (Table 12) prevented the

Table 10. Effects of added AMP on carbohydrate metabolism in pigeon-liver homogenate (well-fed bird)

Conditions were as described in Table 2. The tissue dry wt. was $80 \mathrm{mg} . / \mathrm{cup}$.

\begin{tabular}{|c|c|c|c|c|c|c|c|c|}
\hline $\begin{array}{l}\text { Cup no. ... } \quad \cdots \quad \quad \cdots \\
\text { Additions: }\end{array}$ & $\cdots$ & Initial & 1 & 2 & 3 & 4 & 5 & 6 \\
\hline Lactate (mM) ... & $\ldots$ & & & & & 40 & 40 & 40 \\
\hline $\operatorname{AMP}(\mathbf{m}) \quad \ldots$ & $\ldots$ & & & & $2 \cdot 5$ & & & $\mathbf{2 \cdot 5}$ \\
\hline Time of incubation (min.) & ... & 0 & 15 & 45 & 45 & 15 & 45 & 45 \\
\hline \multicolumn{9}{|c|}{ Metabolites found ( $\mu$ moles/cup): } \\
\hline Glucose & & $12 \cdot 2$ & $20 \cdot 8$ & $15 \cdot 9$ & $9 \cdot 4$ & $19 \cdot 6$ & $18 \cdot 8$ & $15 \cdot 0$ \\
\hline Glucose + glycogen & & $71 \cdot 2$ & $71 \cdot 5$ & $70 \cdot 3$ & $60 \cdot 0$ & $70 \cdot 5$ & $74 \cdot 8$ & $63 \cdot 7$ \\
\hline Glycogen & & $59 \cdot 0$ & $50 \cdot 7$ & $54 \cdot 4$ & $50 \cdot 6$ & $50 \cdot 9$ & $56 \cdot 0$ & $48 \cdot 7$ \\
\hline \multicolumn{9}{|c|}{$\begin{array}{l}\text { Changes between } 15 \text { and } 45 \mathrm{~min} . \\
(\mu \text { moles/cup }):\end{array}$} \\
\hline Glucose & & & & $-4 \cdot 9$ & $-11 \cdot 4$ & & -0.8 & $-4 \cdot 6$ \\
\hline Glucose + glycogen & & & & $-1 \cdot 2$ & $-11 \cdot 5$ & & $+4 \cdot 3$ & $-6 \cdot 8$ \\
\hline Glycogen & & & & $+3 \cdot 7$ & $-0 \cdot 1$ & & $+5 \cdot 1$ & $-2 \cdot 2$ \\
\hline
\end{tabular}

Table 11. Effects of AMP on the concentration of intermediates of carbohydrate metabolism in pigeon-liver homogenate (well-fed bird)

The values refer to the experiment described in Table 10, where conditions of incubation are given.

\begin{tabular}{|c|c|c|c|c|c|c|c|}
\hline $\begin{array}{l}\text { Cup no. ... } \\
\text { Additions }\end{array}$ & Initial & $\begin{array}{c}1 \\
\text { None }\end{array}$ & $\begin{array}{c}2 \\
\text { None }\end{array}$ & $\begin{array}{c}3 \\
\text { AMP }\end{array}$ & $\begin{array}{c}4 \\
\text { Lactate }\end{array}$ & $\begin{array}{c}5 \\
\text { Lactate }\end{array}$ & $\begin{array}{c}6 \\
\text { AMP+ } \\
\text { lactate }\end{array}$ \\
\hline Time of incubation (min.) & $\ldots$ & 15 & 45 & 45 & 15 & 45 & 45 \\
\hline \multicolumn{8}{|c|}{ Intermediates found ( $\mu$ moles/cup) } \\
\hline Glucose 6-phosphate & $0 \cdot 78$ & 0.79 & $0 \cdot 75$ & $0 \cdot 52$ & $1 \cdot 08$ & $1 \cdot 20$ & $0 \cdot 86$ \\
\hline Fructose 6-phosphate & $0 \cdot 26$ & 0.25 & $0 \cdot 24$ & $0 \cdot 18$ & 0.35 & 0.39 & $0 \cdot 30$ \\
\hline Fructose diphosphate & $0 \cdot 13$ & 0.25 & 0.55 & $5 \cdot 11$ & $0 \cdot 12$ & $0 \cdot 11$ & $0 \cdot 14$ \\
\hline Triose phosphates & 0.26 & 0.65 & $1 \cdot 62$ & $8 \cdot 58$ & $0 \cdot 21$ & $0 \cdot 17$ & $0 \cdot 28$ \\
\hline$\alpha$-Glycerophosphate & $1 \cdot 66$ & 0.51 & $0 \cdot 27$ & $0 \cdot 58$ & $5 \cdot 12$ & $7 \cdot 86$ & $14 \cdot 5$ \\
\hline 3-Phosphoglycerate & $0 \cdot 32$ & $0 \cdot 30$ & $0 \cdot 30$ & $0 \cdot 14$ & 0.45 & 0.49 & $0 \cdot 21$ \\
\hline 2-Phosphoglycerate & $0 \cdot 07$ & 0.06 & 0.05 & $0 \cdot 03$ & 0.06 & 0.08 & 0.04 \\
\hline Phosphoenolpyruvate & $0 \cdot 14$ & $0 \cdot 13$ & $0 \cdot 14$ & $0 \cdot 06$ & $0 \cdot 28$ & 0.26 & $0 \cdot 15$ \\
\hline Pyruvate & $0 \cdot 10$ & $0 \cdot 10$ & $0 \cdot 09$ & $0 \cdot 04$ & 0.35 & 0.38 & $0 \cdot 19$ \\
\hline Lactate & $2 \cdot 45$ & $1 \cdot 10$ & $0 \cdot 52$ & $0 \cdot 71$ & $149 \cdot 1$ & $124 \cdot 0$ & $119 \cdot 5$ \\
\hline \multicolumn{2}{|c|}{ Change in lactate ( $\mu$ moles/cup) } & $-1 \cdot 35$ & $-1 \cdot 93$ & $-1 \cdot 74$ & -14.8 & $-39 \cdot 9$ & $-44 \cdot 4$ \\
\hline
\end{tabular}


Table 12. Effect of iodoacetate and AMP on pigeon-liver homogenate (well-fed bird)

Each cup contained $4 \mathrm{ml}$. of homogenate. AMP was added at $15 \mathrm{~min}$. during the incubation of $45 \mathrm{~min}$.; iodoacetate was present initially. The tissue dry wt. was $83 \mathrm{mg}$./cup.

\begin{tabular}{|c|c|c|c|c|c|}
\hline $\begin{array}{llll}\text { Cup. no. } & \cdots & \cdots & \cdots \\
\text { Additions: } & \cdots & \cdots\end{array}$ & Initial & 1 & 2 & 3 & 4 \\
\hline $\mathrm{NAD}^{+}(\mathrm{mM})$ & & 0.5 & 0.5 & 0.5 & 0.5 \\
\hline Sodium iodoacetate $(\mathrm{mM}) \ldots$ & & & & $0 \cdot 25$ & $0 \cdot 25$ \\
\hline AMP (mM) ... & & & $2 \cdot 5$ & & 2.5 \\
\hline \multicolumn{6}{|l|}{ Intermediates found ( $\mu$ moles/cup) } \\
\hline Glucose + glycogen & 33.7 & $25 \cdot 2$ & $20 \cdot 2$ & $33 \cdot 2$ & $22 \cdot 8$ \\
\hline Glucose & $8 \cdot 45$ & $5 \cdot 98$ & $4 \cdot 23$ & 13.5 & $10 \cdot 0$ \\
\hline Glycogen & $25 \cdot 2$ & $19 \cdot 2$ & $16 \cdot 0$ & $19 \cdot 7$ & $12 \cdot 8$ \\
\hline Fructose diphosphate & 0.06 & 0.07 & $0 \cdot 10$ & 0.09 & $7 \cdot 80$ \\
\hline Triose phosphates & $0 \cdot 19$ & $0 \cdot 26$ & 0.32 & 0.47 & $10 \cdot 1$ \\
\hline$\alpha$-Glycerophosphate & $1 \cdot 39$ & 0.31 & $0 \cdot 54$ & 1.02 & $1 \cdot 19$ \\
\hline
\end{tabular}

Table 13. Effects of 2,4-dinitrophenol on carbohydrate synthesis in pigeon-liver homogenate (starved bird)

Each cup contained $4 \mathrm{ml}$. of homogenate incubated for $45 \mathrm{~min}$. The medium contained lactate $(40 \mathrm{~mm})$ but no added glucose; the concentration of $P_{1}$ was $20 \mathrm{~mm}$. The tissue dry wt. was $74 \cdot 1 \mathrm{mg}$./cup.

\begin{tabular}{|c|c|c|c|c|}
\hline $\begin{array}{l}\text { Cup.no. } \quad \ldots \\
\text { Dinitrophenol (mM)... } \\
\mathrm{O}_{2} \text { uptake }(\mu \text { moles } / \text { cup })\end{array}$ & $\begin{array}{lc}\ldots & 1 \\
\ldots & 0 \\
\ldots & -70 \cdot 4\end{array}$ & $\begin{array}{c}2 \\
0 \cdot 02 \\
-72 \cdot 3\end{array}$ & $\begin{array}{c}3 \\
0 \cdot 05 \\
-70 \cdot 5\end{array}$ & $\begin{array}{r}4 \\
0 \cdot 1 \\
-68 \cdot 8\end{array}$ \\
\hline \multicolumn{5}{|c|}{ Metabolites found ( $\mu$ moles/cup) } \\
\hline Glucose & 13.9 & $13 \cdot 2$ & $7 \cdot 17$ & $2 \cdot 68$ \\
\hline Glucose + glycogen & $18 \cdot 1$ & $15 \cdot 7$ & $10 \cdot 1$ & $5 \cdot 18$ \\
\hline Glucose 6-phosphate & $0 \cdot 88$ & 0.80 & 0.59 & $0 \cdot 28$ \\
\hline Fructose 6-phosphate & 0.22 & 0.22 & $0 \cdot 14$ & 0.05 \\
\hline Fructose 1,6-diphosphate & 0.03 & 0.03 & 0.03 & $0 \cdot 05$ \\
\hline Triose phosphates & $0 \cdot 12$ & $0 \cdot 14$ & $0 \cdot 12$ & $0 \cdot 23$ \\
\hline$\alpha$-Glycerophosphate & $2 \cdot 78$ & $4 \cdot 02$ & $3 \cdot 63$ & $4 \cdot 42$ \\
\hline Pyruvate & 0.77 & 0.36 & 0.29 & $0 \cdot 25$ \\
\hline ATP & 0.97 & 0.90 & 0.84 & $0 \cdot 37$ \\
\hline ADP & 0.32 & 0.38 & 0.50 & 0.71 \\
\hline AMP & 0.05 & $0 \cdot 10$ & $0 \cdot 15$ & $0 \cdot 46$ \\
\hline
\end{tabular}

removal of total carbohydrate during incubation (although breakdown of glycogen to glucose occurred), and the concentrations of intermediates did not increase significantly. When AMP was added, however, a large amount of carbohydrate disappeared: this could be accounted for quantitatively as fructose diphosphate and triose phosphates. This confirms the conclusions reached above that the primary effects of AMP were on phosphofructokinase and fructose diphosphatase (effects 1 and 2).

Effects of 2,4-dinitrophenol. Experiments with dinitrophenol were carried out to ascertain whether interference with the maintenance of ATP synthesis would simulate the effects of AMP addition in a specific way. The ATP concentration fell slightly at $0.05 \mathrm{~mm}$-dinitrophenol, and by about $60 \%$ at 0.1 mM-dinitrophenol (Table 13). There were corre- sponding rises in the concentrations of AMP and ADP. These changes of the adenine nucleotides were paralleled by a fall in carbohydrate synthesis. Though there was no accumulation of fructose diphosphate or triose phosphates, the concentration of glucose 6-phosphate was decreased and that of $\alpha$-glycerophosphate increased. It is thus feasible that the effects of dinitrophenol on carbohydrate metabolism were due to the rise in the concentration of AMP.

Effects of the addition of ADP and ATP. The addition of ADP or ATP caused changes similar to those obtained with AMP. This may be expected, owing to the ready interconversion of the adenine nucleotides. No evidence was obtained to indicate that ATP has specific effects, except that, in homogenates of well-fed bird livers with high initial glycogen content, high concentrations $(5 \mathrm{~mm})$ of 
ATP caused rapid glycogenolysis with increases in free glucose and glucose 6-phosphate; this was possibly due to activation of glycogen phosphorylase by $3^{\prime}, 5^{\prime}$-(cyclic)-AMP formed from ATP.

\section{DISCUSSION}

Control of phosphofructokinase and fructose diphosphatase by adenine nucleotides. The results obtained with pigeon-liver homogenates (especially the stimulation of glucose synthesis by AMP, and the evidence indicating that points of action of AMP are phosphofructokinase and fructose diphosphatase) support the concept that the reactions catalysed by phosphofructokinase and fructose diphosphatase are among those which limit the rate of glycolysis and gluconeogenesis respectively, and that the concentrations of intracellular modifiers, in particular AMP and ATP, regulate the activity of these enzymes. The fact that AMP at low concentrations $(0.2 \mathrm{mM})$ is a powerful inhibitor of fructose diphosphatase, as well as a powerful activator of phosphofructokinase, suggests that AMP is in the present system the most important single modifier among the various cell constituents which can influence the activities of the two enzymes, though ADP has similar effects on phosphofructokinase, the quantitative significance of which cannot yet be assessed. The concentration of AMP is a particularly apt 'signal' for regulating glycolysis and gluconeogenesis, as an energyyielding and an energy-consuming process, because it is directly linked to the energy status of the cell, i.e. the concentration of ATP. The concentrations of AMP and ATP are governed by the equilibrium constant $K=[\mathrm{AMP}][\mathrm{ATP}] /[\mathrm{ADP}]^{2}$ of the adenylate-kinase reaction. As the activity of this enzyme is sufficiently high to maintain the concentrations of the three reactants near equilibrium, a fall in the concentration of ATP will cause a rise in the concentration of AMP, and this, by activating phosphofructokinase, will increase the rate of ATP synthesis. On the other hand, if the adenine nucleotides of the cell are present predominantly as ATP, the AMP concentration will be low, phosphofructokinase blocked and the pathway of gluconeogenesis open.

The kinetics of the AMP effect on phosphofructokinase are very intricate because they depend not only on the concentration of AMP but also on those of $\mathrm{Mg}^{2+}$ and of ATP (see Table 14) and, as the concentrations of cell constituents may differ from compartment to compartment within tissue homogenates, it is not possible to predict the degree of inhibition of activation from information on the overall concentration of AMP alone. The kinetics of the AMP inhibition of fructose diphosphatase appear to be less involved, though they depend on the concentration of $\mathrm{Mg}^{2+}$ (Table 14) as expected because of the formation of chelates between AMP and $\mathrm{Mg}^{2+}$. Rather lower concentrations of AMP (below $0.1 \mathrm{mM}$ ) are needed for an almost complete inhibition of fructose diphosphatase than for the activation of phosphofructokinase (above $0.1 \mathrm{mM}$ ). These characteristics, according to available data, bear on the co-ordinated control of the two enzymes: at very low concentrations of AMP when fructose diphosphatase is active phosphofructokinase is inactive, being inhibited by ATP; as the concentration of AMP rises fructose diphosphatase becomes

Table 14. Effects of various 'modifiers' on fructose diphosphatase and phosphofructokinase of liver

The values illustrate that inhibitions depend on the presence of various substances in the medium. They are selected from data of Underwood \& Newsholme $(1965 a, b)$, obtained with partially purified rat-liver enzymes. The substrate for fructose diphosphatase was fructose diphosphate and that for phosphofructokinase glucose 6-phosphate, phosphohexose isomerase being present. It is emphasized that the values indicate only the order of magnitude of the effects involved; there are complicating factors, such as the effects of enzyme dilution, that make precise statements on inhibitions difficult.

\begin{tabular}{|c|c|c|c|c|}
\hline Metabolite & $\begin{array}{c}\text { Concn. of } \\
\text { substrate } \\
\text { (mM) }\end{array}$ & $\begin{array}{l}\text { Concn. } \\
\text { of } \mathrm{Mg}^{2+} \\
(\mathrm{mM})\end{array}$ & $\begin{array}{l}\text { Fructose } \\
\text { diphos- } \\
\text { phatase }\end{array}$ & $\begin{array}{c}\text { Phospho- } \\
\text { fructo- } \\
\text { kinase }\end{array}$ \\
\hline $0.1 \mathrm{mM}-\mathrm{AMP}$ & $0 \cdot 1$ & 5 & 95 & \\
\hline $0.05 \mathrm{mM}-\mathrm{AMP}$ & $0 \cdot 1$ & 0.5 & 98 & \\
\hline - & $0 \cdot 1$ & 5 & 20 & \\
\hline 一 & 0.25 & 0.5 & 15 & \\
\hline $0.16 \mathrm{mM}-\mathrm{ATP}$ & $\mathbf{3} \cdot \mathbf{3}$ & 5 & & 100 \\
\hline $0.16 \mathrm{~mm}-\mathrm{ATP}, 0.3 \mathrm{~mm}-\mathrm{AMP}$ & $3 \cdot 3$ & 5 & & 18 \\
\hline $1.2 \mathrm{mM}$-ATP, $0.6 \mathrm{~mm}$-AMP & $\mathbf{3 \cdot 3}$ & 5 & & 90 \\
\hline $0.01 \mathrm{mM}-\mathrm{ATP}$ & $\mathbf{3} \cdot \mathbf{3}$ & 5 & & 0 \\
\hline $0.01 \mathrm{~mm}$-ATP, $0.5 \mathrm{~mm}$-citrate & $\mathbf{3} \cdot \mathbf{3}$ & 5 & & 50 \\
\hline
\end{tabular}


inactivated before phosphofructokinase is activated. This avoids a wastage of energy through the occurrence of the futile cycle:

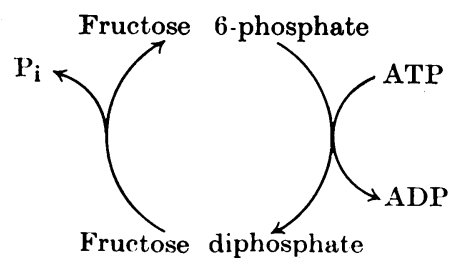

The data of Table 5 indicate that this cycle occurred in the homogenates (to which AMP was added) at a certain range of AMP concentrations, but this does not imply that it occurs in vivo.

It is not yet clear whether a physiological significance can be attributed to the inhibition of fructose diphosphatase by fructose diphosphate. So far inhibitory concentrations have not been demonstrated in vivo.

Intracellular distribution of enzyme inhibitors and activators, and the control of enzymes by active transport of modifiers. The overall concentration of ATP in homogenates was, in some experiments, high enough, considering the concentration of the de-inhibitors fructose 6-phosphate, fructose diphosphate, $\mathrm{P}_{1}$ and AMP, to cause a virtually complete inhibition of phosphofructokinase (Underwood \& Newsholme, 1965b). In fact phosphofructokinase was not inactivated. This indicates that certain quantitative characteristics of the enzyme change on purification and dilution, as suggested by the observations of Underwood \& Newsholme (1965b), or, more likely, that the concentration of ATP at the site of the enzyme was substantially below the average concentration in the homogenate. Two factors could be responsible for this. One is the uneven distribution of adenine nucleotides between the mitochondria and the cytoplasm or medium (see Frunder, Blume, Thielmann \& Börnig, 1961 ; Loiselle \& Denstedt, 1964), which causes the ATP concentration in the mitochondria to be substantially higher than in the soluble phase. The second factor is chelation of ATP with $\mathrm{Mg}^{2+}$ and $\mathrm{Ca}^{2+}$.

It follows from these considerations that the movement of adenine nucleotides into and out of the mitochondria and other organelles could be a major factor in the regulation of metabolic processes. This is also true for other solutes that can be actively accumulated by mitochondria and that can affect the activity of pace-maker enzymes. Active transport into the mitochondria has been shown, for example, for $\mathrm{Ca}^{2+}$ (see Ernster \& Lee, 1964 ; Drahota, Carafoli, Rossi, Gamble \& Lehninger, 1965; Carafoli, Rossi \& Lehninger, 1965; Chance, 1965), $\mathrm{Mg}^{2+}$ (Carafoli, Rossi \& Lehninger,
1964), $P_{1}$ (Greenawalt, Rossi \& Lehninger, 1964; Rossi \& Lehninger, 1964; Vasington \& Greenawalt, 1964), citrate (Schneider, Striebich \& Hogeboom, 1956; Gamble, 1965) and ATP and ADP (Carafoli et al. 1965). ATP, ADP, $\mathrm{P}_{\mathrm{i}}$ and citrate, apart from being reactants in various processes, regulate, as mentioned above, the activity of phosphofructokinase; $\mathrm{Ca}^{2+}$ inhibits pyruvate kinase and pyruvate carboxylase, and $\mathrm{Mg}^{2+}$ activates these enzymes.

Though much attention has been paid to the mechanism of the active transport of these solutes into the mitochondria, the physiological significance of these energy-consuming movements has not yet been analysed. It may well be the regulation of enzyme activities. Movements of $\mathrm{Ca}^{2+}$ could contribute to the control of pyruvate kinase and pyruvate carboxylase. Under some physiological conditions these two enzymes, which control the fate of pyruvate (whether it forms acetyl-CoA or oxaloacetate), must not be fully active at the same time (see Krebs \& Eggleston, 1965). The two enzymes are present in different cell compartments, pyruvate kinase being cytoplasmic and pyruvate carboxylase a mitochondrial enzyme. Both are inhibited by $\mathrm{Ca}^{2+}$. Hence, if the concentration of $\mathrm{Ca}^{2+}$ is high in the cytoplasm, pyruvate kinase is inhibited and pyruvate carboxylase active, and the situation is reversed by transport of $\mathrm{Ca}^{2+}$ into the mitochondria.

Traffic in one direction of substances that cannot be metabolized, like $\mathrm{Ca}^{2+}$ or $\mathrm{Mg}^{2+}$, would make no biological sense. Thus there must be mechanisms that bring about the release of these substances from the mitochondria into the cytoplasm. This might be entirely passive as Chance (1965) suggests, in which case it occurs continuously according to the concentration gradient and is counteracted by active transport in the opposite direction.

Origin of fructose diphosphate and triose phosphate in pigeon-liver homogenates. The assumption was made by Krebs (1964b) that fructose diphosphate and triose phosphates, which accumulate in the presence of AMP and the absence of lactate, are derived from gluconeogenic precursors. The present experiments indicate that they are predominantly formed from endogenous carbohydrate. However, this does not alter the conclusions previously drawn about the effects on fructose diphosphatase and phosphofructokinase and the mechanism by which lactate removes the accumulated intermediates.

Fructose diphosphatase as a rate-limiting step in gluconeogenesis. Exton \& Park (1965) concluded from measurements of the concentrations of glucose and fructose 6-phosphates, fructose diphosphate and dihydroxyacetone phosphate that fructose diphosphatase is not a rate-limiting stage in gluconeogenesis from lactate in perfused livers from starved rats and that the formation of triose phos- 
phate from pyruvate is the rate-limiting stage. The present experiments are in agreement with this concept, which is also supported by experiments with kidney cortex where substrates forming oxaloacetate without involvement of pyruvate carboxylase form glucose much more rapidly than lactate (Krebs, Bennett, de Gasquet, Gascoyne \& Yoshida, 1963). Exton \& Park (1965) thought that their conclusion was confirmed by the observation that fructose can give rise to glucose at a faster rate than lactate. This was based on the assumption that fructose would enter the gluconeogenic pathway solely at the stage of triose phosphate, an assumption that has recently been shown to be incorrect at the high fructose concentrations $(20 \mathrm{~mm})$ used by Exton \& Park (Di Pietro, 1964). The view that fructose diphosphatase can limit the rate of gluconeogenesis under certain conditions is not invalidated by the conclusion that it is not always a rate-limiting factor.

Role of phosphate acceptor in the control of glucose degradation in liver. It is well established that the concentration of ADP can regulate the rate of the aerobic degradation of substrates generally and this raises the question whether the stimulating effect of adenine nucleotides is, at least in part, due to the formation of ADP and its role as phosphate acceptor. It is possible that this was a component in stimulating the conversion of glucose into pyruvate in the pigeon-liver homogenates, but the following facts show that in this system the main stimulating effects of the adenine nucleotides were those on phosphofructokinase: (1) The stimulation of glucose degradation to pyruvate caused by AMP in the presence of adequate concentrations of $\mathrm{NAD}^{+}$was accompanied by a rise in the concentrations of fructose diphosphate and triose phosphates, and by a fall in those of 3-phosphoglycerate and hexose 6-phosphates (Tables 3, 4 and 11). (2) The increase in the rate of glucose removal when AMP was added was the same when sufficient $\mathrm{NAD}^{+}$was present to saturate the triose phosphate-dehydrogenase system and when the rate of this step was limited by lack of $\mathrm{NAD}^{+}$or by iodoacetate. In the first case, there were small increases in the concentrations of fructose diphosphate and triose phosphates; in the second, the large accumulation of these intermediates accounted quantitatively for the carbohydrate removed (see Tables 3, 4 and 12).

Wenner, Dunn \& Weinhouse (1953) noted that the addition of phosphate acceptor did not affect the rate of formation of ${ }^{14} \mathrm{CO}_{2}$ from $\left[{ }^{14} \mathrm{C}\right]$ glucose in rat-liver homogenates while $\mathrm{NAD}^{+}(2 \mathrm{mM})$, as in the present experiments, was an obligatory requirement for optimum rates of oxidation. Tiedemann \& Born (1963), who studied the effects of adenine nucleotides on the glycolysis of homogenates from ascites-tumour cells, found that phosphate acceptors did not limit the rates and that adenine nucleotides had effects similar to those found with pigeon-liver homogenates. The similarity, of course, is restricted to the control of glucose degradation, as gluconeogenesis does not occur in ascites cells.

Note on the historical developments in the study of the regulatory properties of phosphofructokinase and fructose diphosphatase. A special role of phosphofructokinase in the regulation of glycolysis was first suggested by Cori (1942) on the basis of the observation that, under certain conditions, hexose monophosphate accumulated in muscle while the concentration of fructose diphosphate remained low and no lactate was formed. Cori (1942) concluded that 'this indicates that the reaction between fructose 6-phosphate and ATP ... is a limiting factor as regards the rate at which lactic acid is formed and carbohydrate is oxidized'. Engelhardt \& Sakov (1943) suggested that the activity of phosphofructokinase might be varied by reversible oxidations and reductions. The modern development of ideas about the mechanisms of modifying the activity of the enzyme began with the discovery by Lardy \& Parks (1956) that the enzyme is inhibited by ATP, and their comment 'that this may help explain the lack of hexose diphosphate accumulation in stimulated muscle discussed by Cori'. The next stage was the discovery of Mansour \& Mansour (1962) that the enzyme is activated by $3^{\prime}, 5^{\prime}$-(cyclic)-AMP, followed soon by the work of Passonneau \& Lowry $(1962 a, b)$ showing that the inhibition by ATP is overcome by fructose 6-phosphate, fructose diphosphate and $P_{i}$, and that AMP and ADP activate the enzyme to some extent irrespective of the ATP concentration. Shortly afterwards Parmeggiani \& Bowman (1963), Garland, Randle \& Newsholme (1963) and Passonneau \& Lowry (1963), almost simultaneously, reported the inhibition of phosphofructokinase by citrate.

The observations referred to were made on phosphofructokinase preparations obtained from a variety of different tissues. The enzyme from different sources of different origin seems to be susceptible to modifiers in the same way although there are quantitative differences. This applies to mammalian brain (Passonneau \& Lowry, 1964), striated muscle (Passonneau \& Lowry, 1962a,b), cardiac muscle (Mansour, 1963, 1965) and liver (Passonneau \& Lowry, 1964; Underwood \& Newsholme, 1965b), yeast (Ramaiah, Hathaway \& Atkinson, 1964; Salas, Viñuela, Salas \& Sols, 1965), liver fluke (Mansour \& Mansour, 1962) and Escherichia coli (Atkinson \& Walton, 1965).

The concept that fructose diphosphatase plays a role in the synthesis of glycogen from lactate seems to have been expressed first by Lardy (1949). It was referred to by Olson (1951) and by Pogell \& McGilvery (1952) and elaborated by Krebs (1954). The inhibition of fructose diphosphatase by higher concentrations of fructose diphosphate was found independently by Weber (1964) and Krebs (1963, $1964 a, b)$. The inhibition of fructose diphosphatase by AMP was simultaneously reported by J. S. Williams, D. E. Wilson \& M. F. Utter (personal communication), Taketa \& Pogell (1963) and Newsholme (1963).

W. G. holds an Overseas Research Bursary of the South African Council for Scientific and Industrial Research. This work was supported by a U.S. Public Health Service Grant no. AM08715. The authors are indebted to $\mathrm{Mr}$ T. Gascoyne for technical assistance. 


\section{REFERENCES}

Adam, H. (1963). In Methods of Enzymatic Analysis, p. 573. Ed. by Bergmeyer, H.-U. New York: Academic Press Inc.

Atkinson, D. E. \& Walton, G. M. (1965). J. biol. Chem. 240, 757.

Baronowski, T. (1949). J. biol. Chem. 180, 535.

Berry, M. N. (1964). D.Phil. Thesis: University of Oxford.

Berry, M. N. (1965). Biochem. J. 95, 587.

Bowen, W. J. \& Kerwin, T. D. (1956). Arch. Biophys. Biochem. 64, 278.

Bücher, T. \& Hohorst, H.-J. (1963). In Methods of Enzym. atic Analysis, p. 246. Ed. by Bergmeyer, H.-U. New York: Academic Press Inc.

Burton, K. (1957). Ergebn. Physiol. 49, 275.

Carafoli, E., Rossi, C. S. \& Lehninger, A. L. (1964). J. biol. Chem. 239, 3055.

Carafoli, E., Rossi, C. S. \& Lehninger, A. L. (1965). J. biol. Chem. 240, 2254.

Chance, B. (1965). J. biol. Chem. 240, 2729.

Cori, C. F. (1942). A Symposium on Respiratory Enzymes, p. 173. Madison, Wis.: University of Wisconsin Press.

Crane, R. K. \& Sols, A. (1954). J. biol. Chem. 210, 597.

Crowley, G. J., Moses, V. \& Ullrich, J. (1962). Bio-organic Chem. quart. Rep. Dec. (1962)-Feb. (1963), p. 1.

Dickens, F. \& Simer, F. (1931). Biochem. J. 25, 973.

Di Pietro, D. L. (1964). J. biol. Chem. 239, 4051.

Drahota, Z., Carafoli, E., Rossi, C. S., Gamble, R. L. \& Lehninger, A. L. (1965). J. biol. Chem. 240, 2712.

Dresel, E. I. B. (1953). Biochem. J. 54, 654.

Eggleston, L. V. \& Hems, R. (1952). Biochem. J. 52, 156.

Engelhardt, V. A. \& Sakov, N. E. (1943). Biokhimiya, 8, 9.

Ernster, L. \& Lee, C.-P. (1964). Annu. Rev. Biochem. 33, 729 (see especially p. 763).

Exton, J. H. \& Park, C. R. (1965). J. biol. Chem. 240, PC955.

Frunder, H., Blume, E., Thielmann, K. \& Börnig, H. (1961). Hoppe-Seyl. Z. 325, 146.

Gamble, R. L. (1965). J. biol. Chem. 240, 2668.

Garland, P. B., Randle, P. J. \& Newsholme, E. A. (1963). Nature, Lond., 200, 169.

Greenawalt, J. W., Rossi, C. S. \& Lehninger, A. L. (1964). J. Cell Biol. 23, 21.

Haugaard, N., Inesi, G. \& Blanken, R. R. (1960). Arch. Biochem. Biophys. 90, 31.

Hohorst, H.-J. (1963a). In Methods of Enzymatic Analysis, p. 134. Ed. by Bergmeyer, H.-U. New York: Academic Press Inc.

Hohorst, H.-J. (1963b). In Methods of Enzymatic Analysis, p. 215. Ed. by Bergmeyer, H.-U. New York: Academic Press Inc.

Holten, D. D. \& Nordlie, R. C. (1965). Biochemistry, 4, 723.

Kizer, D. E., Cox, B., Lovig, C. A. \& de Estrugo, S. F. (1963). J. biol. Chem. 238, 3048.

Klingenberg, M. (1963). In Methods of Enzymatic Analysis, p. 528. Ed. by Bergmeyer, H.-U. New York: Academic Press Inc.

Kolthoff, I. M. \& Sandell, E. B. (1952). Textbook of Quantitative Inorganic Analysis, 3rd ed., p. 531. New York: MacMillan and Co.

Krebs, H. A. (1930). Biochem. Z. 220, 250.
Krebs, H. A. (1951). Biochem. J. 48, 349.

Krebs, H. A. (1954). Bull. Johns Hopk. Hosp. 95, 19.

Krebs, H. A. (1963). In Advances in Enzyme Regulation, vol. 1, p. 395. Ed. by Weber, G. New York: Pergamon Press Inc.

Krebs, H. A. (1964a). In Advances in Enzyme Regulation, vol. 2, p. 71. Ed. by Weber, G. New York: Pergamon Press Inc.

Krebs, H. A. (1964b). Proc. Roy. Soc. B, 159, 545.

Krebs, H. A., Bennett, D. A. H., de Gasquet, P., Gascoyne, T. \& Yoshida, T. (1963). Biochem. J. 86, 22.

Krebs, H. A., Dierks, C. \& Gascoyne, T. (1964). Biochem. J. 93, 112.

Krebs, H. A. \& Eggleston, L. V. (1965). Biochem. J. 84, 3c.

Krebs, H. A. \& Hems, R. (1964). Biochem. J. 93, 623.

Lamprecht, W. \& Trautschold, I. (1963). In Methods of Enzymatic Analysis, p. 543. Ed. by Bergmeyer, H.-U. New York: Academic Press Inc.

Lardy, H. A. (1949). In Respiratory Enzymes, p. 188. Ed. by Lardy, H. A. Minneapolis: Burgess Publishing Co.

Lardy, H. A. \& Parks, R. E., jun. (1956). In Enzymes: Units of Biological Structure and Function, p. 584. Ed. by Gaebler, O. New York: Academic Press Inc.

Loiselle, J.-M. \&Denstedt, O. F. (1964). Canad.J. Biochem. $42,21$.

Lowry, O. H., Passonneau, J. V., Hasselberger, F. X. \& Schulz, D. W. (1964). J. biol. Chem. 239, 18.

Mansour, T. E. (1963). J. biol. Chem. 238, 2285.

Mansour, T. E. (1965). J. biol. Chem. 240, 2165.

Mansour, T. E. \& Mansour, J. M. (1962). J. biol. Chem. 237, 629.

Meldrum, N. U. \& Roughton, F. J. W. (1933). J. Physiol. $80,113$.

Newsholme, E. A. (1963). Biochem. J. 89, 38 P.

Oliver, I. T. (1955). Biochem. J. 61, 116.

Olson, R. E. (1951). Cancer Res. 11, 571.

Pardee, A. B. (1949). J. biol. Chem. 179, 1085.

Parmeggiani, A. \& Bowman, R. H. (1963). Biochem. biophys. Res. Commun. 12, 268.

Passonneau, J. V. \& Lowry, O. H. (1962a). Biochem. biophys. Res. Commun. 7, 10.

Passonneau, J. V. \& Lowry, O. H. (1962b). Fed. Proc. 21, 87.

Passonneau, J. V. \& Lowry, O. H. (1963). Biochem. biophys. Res. Commun. 13, 372.

Passonneau, J. V. \& Lowry, O. H. (1964). In Advances in Enzyme Regulation, vol. 2, p. 265. Ed. by Weber, G. New York: Pergamon Press Inc.

Pfleiderer, G. (1963). In Methods of Enzymatic Analysis, p. 381. Ed. by Bergmeyer, H.-U. New York: Academic Press Inc.

Pinter, K., Hamilton, J. G. \& Miller, O. N. (1963). Analyt. Biochem. 4, 458.

Pogell, B. M. \& McGilvery, R. W. (1952). J. biol. Chem. 197, 293.

Ramaiah, A., Hathaway, J. A. \& Atkinson, D. E. (1964). J. biol. Chem. 239, 3619.

Recknagel, R. O. \& Potter, V. R. (1951). J. biol. Chem. $191,263$.

Rossi, C. S. \& Lehninger, A. L. (1964). J. biol. Chem. 239, 3971.

Sakami, W. (1955). Handbook of Isotope Tracer Methods. Cleveland, Ohio: Western Reserve University. 
Salas, M. L., Viñuela, E., Salas, M. \& Sols, A. (1965). Biochem. biophys. Res. Commun. 19, 371.

Schneider, W. C., Striebich, M. J. \& Hogeboom, G. H. (1956). J. biol. Chem. $222,969$.

Segal, H. L. \& Brenner, B. M. (1960). J. biol. Chem. 235, 471.

Taketa, K. \& Pogell, B. M. (1963). Biochem. biophys. Res. Commun. 12, 229.

Tiedemann, H. \& Born, J. (1963). Hoppe-Seyl. Z. 334, 215.

Underwood, A. H. \& Newsholme, E. A. (1965a). Biochem. J. 95, 767.

Underwood, A. H. \& Newsholme, E. A. (1965b). Biochem. J. 95, 868.

Vasington, F. D. \& Greenawalt, J. W. (1964). Biochem. biophys. Res. Commun. 15, 133.
Velick, S. F. \& Furfine, C. (1963). In The Enzymes, vol. 7, p. 243. Ed. Boyer, P. D., Lardy, H. A. \& Myrbäck, K. New York: Academic Press Inc.

Warburg, O. (1925). Biochem. Z. 164, 481.

Warburg, O., Geissler, A. W. \& Lorenz, S. (1962). In New Methods in Cell Physiology, p. 518. New York: Interscience Publishers Inc.

Warburg, O. \& Krippahl, G. (1960). Z. Naturf. 156, 364.

Warburg, O. \& Yabusoe, M. (1924). Biochem. Z. 146, 380.

Weber, G. (1964). In Fructose Diphosphatase and its Role in Gluconeogenesis, p. 81. Ed. by McGilvery, R. W. \& Pogell, B. M. Baltimore: Port City Press Inc.

Weil-Malherbe, H. \& Bone, A. D. (1951). Biochem. J. 49, 339.

Wenner, C. E., Dunn, D. F. \& Weinhouse, S. (1953). $J$. biol. Chem. 205, 409. 